\title{
Chapter 14 \\ Taxation of the Platform Economy: Challenges and Lessons for Social Security
}

\section{Katerina Pantazatou}

\section{Introduction}

The digital economy encompasses various different business models mediating technology in multi-sided markets (such as social networks, online marketplaces, and sharing economy platforms) and highly specialised services in single-sided markets (for example, cloud computing, diagnostics, etc.). ${ }^{1}$ The platform economy constitutes a sub-area of the digital economy. Variously called the platform, sharing, collaborative, gig or "peer-to-peer" (P2P) economy, and sometimes described as collaborative consumption or crowd-based capitalism, ${ }^{2}$ all terms intend to describe an economic model in which individuals are able to borrow or rent assets owned by someone else. ${ }^{3}$ This contribution aims to shed some light on issues arising from the taxation of the platform economy. While it is rather obvious that the purposes of labour law, social security law and tax law differ, this chapter will attempt to answer the question whether any lessons can be learned for social law from the treatment of platforms and platform workers in tax law.

As will be discussed, tax law, both at an international and EU level, has focused mostly on how to ensure that the profits of the platforms are taxed

1 Kofler, Georg/Mayer, Gunter/Schlager, Christoph, Taxation of the Digital Economy: A Pragmatic Approach to Short-Term Measures, in: European Taxation, 58 (2018) 4, p. 123.

2 This term was coined by Sundararajan, Arun, The Sharing Economy: The End of Employment and the Rise of Crowd-Based Capitalism, Cambridge: MIT Press 2016, p. 27.

3 Schneider, Henrique, Creative Destruction and the Sharing Economy: Uber as Disruptive Innovation, Cheltenham: Edward Elgar Publishing 2018, p. 6. Throughout this chapter, these terms, and in particular the terms "sharing economy" and "platform economy" are used interchangeably. 
where they should. ${ }^{4}$ Similarly, it is the taxation of the digital economy, and not the sub-area of the platform economy, that is in the spotlight in the discussions of policy makers. These two facts taken together have contributed to the absence of clear proposals as to the taxation of the platform economy, and more specifically the taxation of "platform workers". While some discussion at policy level has been initiated recently, ${ }^{5}$ the approaches and solutions rest with individual countries and are very far from being coordinated.

The present chapter will provide an account of the main problem arising from a tax law perspective in the taxation of platform workers, it will highlight the importance (or lack thereof) of the taxation of the platform, and will examine some solutions put forward in different jurisdictions. It will conclude by attempting to answer whether there is anything for social law to learn from tax law and whether taxation, one of the main sources of financing social protection, is adequately prepared to deal with the platform economy challenges.

\section{Platform-Related Issues and International Initiatives}

Despite the challenges it poses, the taxation of the platform economy has received little attention in the recent EU and international proposals that focus primarily on the taxation of the digital economy. The recent proposals aim to find ways to tax the big multinational corporations operating in the digital economy, like Facebook and Google, ${ }^{6}$ which are usually taxed in their place of residence (which is often the US) yet escape taxation in other places where they create profits. It is obvious that the potential of taxing Facebook in other states on the basis, for instance, of its number of users there will bring much more revenue to those states, as opposed to the taxation of the "platform workers".

4 The place of the taxation of these profits is a debatable issue in taxation. Several concepts have been put forward to substitute the required physical presence of the platform as a nexus for taxing. One of those is "value creation".

5 See for instance Milanez, Anna/Bratta, Barbara, Taxation and the Future of Work: How Tax Systems Influence Choice of Employment Form, in: OECD Taxation Working Papers, No. 41, OECD Publishing, Paris, 2019, https://doi.org/10.1787/20 f7164a-en. Accessed 10 July 2020.

6 Note, for instance, the GAFA tax (Google, Apple, Facebook and Amazon) adopted in France in July 2019, which imposes a 3 percent levy on the total annual revenues of the largest technology firms providing services to French consumers. 
Placing this in the context of the platform economy, it comes as no surprise that both the OECD and the EU focus on how they can tax the profits of Airbnb and Uber instead of the Airbnb host and the Uber driver. ${ }^{7}$ Consequently, it is the taxation of the platform itself that has attracted the focus of international proposals and recommendations, and notably the question where to tax the profits of the platforms operating in the digital economy, in absence of a physical presence in the countries where they operate. ${ }^{8}$ But even in this case, a uniform definition of a platform does not exist, as each one of them employs different business models. The question is not merely rhetorical as one common definition encompassing a number of those models would allow for a common tax treatment of the different platforms and platform workers. ${ }^{9}$

EU and international initiatives have focused on how to allow Member States (or third countries) to tax the profits of companies that have no physical presence in the respective country; yet, they certainly contribute to value creation. By allowing for the fiction of the "digital presence" or "significant economic presence evidenced via digital technology and other automated means"10 and by ensuring that taxation will arise wherever a Multinational Enterprise (MNE) has a "virtual permanent establishment", ${ }^{11}$ the recent proposals aimed to thwart the outdated idea that an enterprise needs to be physically present in a country to supply goods or services in that market. However, the proposals as to how to best tackle this

7 The different proposals are discussed in the last sections. Among the different solutions put forward is the suggestion to tax the platform's profits where "value is created", that is where the profits arise and where the service is provided, instead of the place of the tax residence of the corporation.

8 See for instance, OECD, Tax Challenges Arising from Digitalisation - Interim Report 2018: Inclusive Framework on BEPS, OECD/G20 Base Erosion and Profit Shifting Project, OECD Publishing, Paris, 2018, (hereinafter "2018 OECD Interim Report”) p. 196, http://dx.doi.org/10.1787/9789264293083-en. Accessed 10 July 2020; European Commission, Proposal for a Council Directive laying down rules relating to the corporate taxation of a significant digital presence, COM (2018) 147 final (hereinafter "2018 SDP Directive Proposal”).

9 Pantazatou, Katerina, The Taxation of the Sharing Economy, in: Haslehner, Werner/Kofler, Georg/Pantazatou, Katerina/Rust, Alexander (eds.), Tax and the Digital Economy: Challenges and Proposals for Reform, Alphen aan den Rijn: Wolters Kluwer 2019, pp. 215-236, at 217.

10 OECD, Addressing the Tax Challenges of the Digitalisation of the Economy. Public Consultation Document. 13 February - 6 March 2019, https://www.oecd.org/t ax/beps/public-consultation-document-addressing-the-tax-challenges-of-the-digitali sation-of-the-economy.pdf. Accessed 10 July 2020.

11 OECD, 2018 OECD Interim Report (fn. 8), p. 160. 
issue were many, each one of them coming with its own set of problems, such as the allocation of profits across countries. ${ }^{12}$ In 2018, the Commission followed the OECD's initiatives and published proposals for two Council Directives on the taxation of the digital economy ${ }^{13}$ and one (nonbinding) Commission Recommendation relating to the corporate taxation of a significant digital presence (SDP). ${ }^{14}$ These proposals have now been put "on hold" in favour of the OECD's suggested "Unified Approach". ${ }^{15}$ In 2019 , the OECD attempted to find the commonalities among the different proposals and agree on a "Unified Approach" towards the tax challenges raised by the digitalisation of the economy. ${ }^{16}$

In January 2020, the OECD came up with a new proposal on a "Unified Approach" hoping that consensus will be reached among the participating countries regarding the best way to address the challenges arising from the taxation of the digital economy. ${ }^{17}$ The proposal focused on the taxation of the platforms and advocated, inter alia, the creation of a new nexus for the taxation of the platforms' profits, not dependent on physical presence but largely based on sales, a profit allocation rule and mechanisms to ensure greater legal certainty. ${ }^{18}$

While the aforementioned reports and proposals have been inadequate in tackling the taxation of the platform workers, the 2018 OECD Interim Report acknowledged that the focus, with regard to the sharing economy, should be placed on the contractual relationship between the platforms and

12 These proposals included the "user participation", "marketing intangibles", and "significant economic presence" proposals.

13 European Commission, Proposal for a Council Directive on the Common System of a Digital Services Tax on Revenues resulting from the Provision of Certain Digital Services, COM (2018) 148 final as well as 2018 SDP Directive Proposal (fn. 8).

14 European Commission, European Commission Recommendation of 21 March 2018 relating to the Corporate Taxation of a Significant Digital Presence, COM (2018) 1650 final.

15 OECD, Statement by the OECD/G20 Inclusive Framework on BEPS on the TwoPillar Approach to Address the Tax Challenges Arising from the Digitalisation of the Economy, January 2020, https://www.oecd.org/tax/beps/statement-by-the-oecd -g20-inclusive-framework-on-beps-january-2020.pdf. Accessed 10 June 2020.

16 OECD, Public Consultation Document: Secretariat Proposal for a "Unified Approach" under Pillar One, November 2019, p. 4, https://www.oecd.org/tax/beps/p ublic-consultation-document-secretariat-proposal-unified-approach-pillar-one.pdf. Accessed 10 July 2020.

17 OECD, Statement by the OECD/G20 Inclusive Framework on BEPS on the TwoPillar Approach to Address the Tax Challenges Arising from the Digitalisation of the Economy (fn. 15).

18 Ibid. 
the service providers, as the grey zones that can be found therein could lead to a minimisation of both tax liability and the tax base. ${ }^{19}$ In the context of the platform economy, focusing on the platform worker would indeed make sense, as on average, the "service provider" rather than the platform receives over 85 percent of the transaction value. ${ }^{20}$

Nevertheless, as the sections below will show, the platform and its taxation does play a role in the taxation of the platform workers. One way this may happen is through its classification and placement in the appropriate legal and regulatory environment, which, in turn, may affect the employment relationship between the platform and the platform workers and, thus, their taxation. Another way is by providing tax incentives to the platform to create or opt for a particular work status of its workers (whether this is an employment status or an independent contractor's status). I now turn to explore these two possibilities.

\section{Relationship of Platform and Work Status}

This section will attempt to explain how the classification of the platform may influence the work status of "gig workers" and, in turn, their taxation. As will be argued, the "worker classification" question relates (also) to the classification of the platform. An Uber driver does not necessarily need to be classified for tax purposes in the same way as an Airbnb host or a "BlaBlaCar" driver. The classification, for example, of an Uber driver as an independent contractor, a worker or an employee, cannot be considered independently of the classification of the platform and the nature of the services it requires. ${ }^{21}$ Consequently, one would have to start by understanding and classifying the services provided by the platforms in the sharing economy, in an attempt to understand the legal relationship between the platform workers and the platform. Two recent CJEU Grand Chamber non-tax-related judgments aimed to shed some light on this problem, ex-

19 OECD, 2018 OECD Interim Report (fn. 8).

20 Elliot, Carrie Brandon, Taxation of the Sharing Economy: Recurring Issues, in: Bulletin for International Taxation 72 (2018) 1: Platform revenue models vary significantly, even within the same commercial sector, but most adopt a fixed or variable commission approach, with commissions ranging from 1 percent to 2 percent of transaction value for crowdlending, to as high as 20 percent for ridesharing.

21 CJEU of 20 December 2017, Case C-434/15, Asociación Profesional Elite Taxi, ECLI:EU:C:2017:981. 
amining, inter alia, the types of services provided by the two "flagship" platforms in the sharing economy, Uber and Airbnb.

The CJEU dealt first with the Uber case, ${ }^{22}$ where it found Uber to be a transportation service provider, instead of a digital platform, as the intermediation service provided by the platform was inherently linked to a transport service. ${ }^{23}$ In its recent case Grand Chamber Airbnb Ireland ${ }^{24}$ the CJEU emphasised that Airbnb was different from Uber. In contrast to Uber, the services provided by Airbnb could be classified as "information society services" within the meaning of Directive 2000/31. In reaching this conclusion, the CJEU considered that even though "the purpose of the intermediation service provided by Airbnb Ireland is to enable the renting of accommodation [...] the nature of the links between those services does not justify departing from the classification of that intermediation service as an "information society service" and therefore the application of Directive 2000/31 to it." ${ }^{25}$ However, in the Court's view and unlike its judgment in Uber, in this case, the intermediation service is so strong and essential that it "cannot be separated from the property transaction itself, in that it is intended not only to provide an immediate accommodation service, but also $[\ldots]$ to provide a tool to facilitate the conclusion of contracts concerning future interactions. It is the creation of such a list for the benefit both of the hosts who have accommodation to rent and persons looking for that type of accommodation which constitutes the essential feature of the electronic platform managed by Airbnb Ireland." (emphasis added). ${ }^{26}$

In reaching this conclusion the Court considered the essential features of each platform, the indispensability of the platform in the delivery of the underlying service as well as the setting or the "capping" of the price to be

22 Ibid.

23 Ibid., para. 48: The services Uber provides “[...] must be interpreted as meaning that an intermediation service such as that at issue in the main proceedings, the purpose of which is to connect, by means of a smartphone application and for remuneration, non-professional drivers using their own vehicle with persons who wish to make urban journeys, must be regarded as being inherently linked to a transport service and, accordingly, must be classified as "a service in the field of transport” within the meaning of Article 58 (1) TFEU. Consequently, such a service must be excluded from the scope of Article 56 TFEU, Directive 2006/123 and Directive 2000/31."

24 CJEU of 19 December 2019, Case C-390/18, Airbnb Ireland, ECLI:EU:C:2019:1112.

25 Ibid., para. 52.

26 Ibid., para. 53. 
charged to the guests. Under all these criteria, the Court found that Uber and Airbnb were different. ${ }^{27}$

The question of the services (and their ancillary or essential character) provided by each platform is fundamental in the assessment of the taxation of both the platform and the Uber driver or the Airbnb host. With regard to the former point, the nature of the services provided by the platform is relevant for the assessment of the VAT to be paid, notably the definition of the place of supply of the service, which decides, inter alia, where the VAT will be paid. This concerns both the $\mathrm{B} 2 \mathrm{~B}$ relationship between the platform and the "supplier"/platform worker as well as the B2C relationship between the platform and the consumer. In turn, the place of supply of the service at issue "to a taxable person acting as such shall be the place where that person has established his business." 28 For instance, if the service at issue were to be classified as a transport service, then the place of supply (and the place where VAT would be payable) would be where the transportation takes place, pursuant to Article 48 of the VAT Directive. ${ }^{29}$

With regard to the second ramification, the legal framework to which the platform is subject will be defined by its classification. In other words, if Uber is classified as (mainly) a transportation service, then it will be subject to the transport policy-related directives. This categorisation may inform other important features in the systematisation of the work status of the "service-providers" on the platform, such as control (i.e. ensuring that the requisite standards of safety and quality are met) or the influence the employer has to exercise over the service-provider and the quality of the services $(s)$ he provides. ${ }^{30}$

27 For more on the comparison of the two cases see Beretta, Giorgio, Airbnb is Not Uber: VAT Reflections on the Airbnb Ireland Case (C-390/18), Blogpost on LinkedIn, 22 December 2019, https://www.linkedin.com/pulse/airbnb-uber-vat-re flections-ireland-case-c-39018-giorgio-beretta/. Accessed 10 July 2020; and Loquet, Erwan/Karoutis, Dimitrios, European Union - VAT Considerations on CJEU's Ruling that Airbnb is Not a Real Estate Agent, in: International VAT Monitor, 31 (2020) 4.

28 Article 44, Directive 2006/112/EC on the Common System of Value Added Tax (6th Recast VAT Directive). On the definition of the taxable person, see infra, under IV. 2. B.

29 See Beretta, Giorgio, Airbnb is Not Uber: VAT Reflections on the Airbnb Ireland Case (C-390/18) (fn. 27).

30 Indeed, the degree of the influence and control of the platform to the "service providers" was decisive in their classification as an "information society services" platform for Airbnb and as a transportation services platform for Uber. In the words of Advocate General Spzunar: "It should be noted, in that regard, that Uber exercised control over the quality of the vehicles and their drivers and also 


\section{Labour-Related Tax Incentives for Platforms}

When looking into the platform economy, one should not overlook that, in general, brick and mortar companies tend to opt for contracting selfemployed workers instead of hiring standard employees, because they face lower tax burdens per worker hired. Indeed, tax incentives may play an important role in platforms' preferences as to what kind of contracts they would like to conclude with their workers. Besides not having to pay social security contributions for independent contractors, tax incentives may consist of deductions from Corporate Income Taxes (CIT) or the absence of the obligation to pay certain taxes (such as payroll taxes), or reduced administrative costs for the platforms. Consequently, taxation may be decisive for the preferences of the platforms as to the "work status" they want their workers to have.

For instance, it has been reported that in the Netherlands, the tax cost of hiring an independent contractor is 37 percent lower compared to the cost of hiring a standard employee, reflecting substantial labour cost savings for firms. ${ }^{31}$ This is because the employer of an independent contractor is not liable for social contributions for the worker. Similarly, the employer/platform can deduct from its corporate income liability labour-related costs or make use of "labour-related" tax allowances and credits against its total CIT liability. ${ }^{32}$ These deductions and allowances obviously vary from country to country and depend on the respective employment. For instance, in Argentina, corporations (and platforms) are allowed to deduct from their CIT base labour costs, including wages, employer social security contributions and employee non-tax compulsory payments (NTCPs) for

over the drivers' conduct by reference to the standards that Uber itself had determined. On the other hand, as is apparent from points 27 and 29 of this Opinion, the control exercised by Airbnb Ireland concerns users' compliance with standards defined or, at the very least, chosen by those users. In any event, as regards Uber's activity, the exercise of the power of administrative control was only one of the factors that led to the assertion that that provider exercised decisive influence over the conditions under which the transport services were provided." See CJEU of 19 December 2019, Case C-390/18, Airbnb Ireland, ECLI:EU:C:2019:1112, para. 76.

31 Milanez, Anna, Gig Workers and the Tax Web, in: OECD Observer, 319 (2019) Q3, https://oecdobserver.org/news/fullstory.php/aid/6278/Gig_workers_and_the_t ax_web.html. Accessed 10 July 2020.

32 Such can be the case, for instance, when an employer hires a person with disabilities. 
standard employment contracts. ${ }^{33}$ In contrast, in Italy, according to the OECD Working Paper, firms are able to deduct the overall employment cost (gross wage plus profits) both when computing the CIT and the IRAP, also when they "employ" independent contractors. ${ }^{34}$

In the same vein, the contractors are entitled to make certain deductions, which vary from country to country, from their income tax, lowering both their own tax burden and their employer's. ${ }^{35}$ When firms/platforms can save a lot on tax-related labour costs by hiring contractors, and when contractors are also in a tax-beneficial position if they are not classified as employees, it is obvious that the tax system at issue promotes demand for independent work.

The recent OECD Working Paper highlights how tax systems may offer tax incentives to both platforms and workers to distort the employment relationship. ${ }^{36}$ Taking the Netherlands as one of the case studies, the OECD Working Paper explains how the Dutch tax system entitles unincorporated self-employed workers to two deductions from personal income tax allowing them to pay less tax than employees. ${ }^{37}$ Consequently, unincorporated self-employed workers have the lowest payment wedge, both at the average wage but also across the wage spectrum. ${ }^{38}$ Indeed, the degree of variation between payment wedges across different employment forms is considerable among the countries studied in the OECD Working Paper. ${ }^{39}$ As the authors note, in countries like Hungary, Italy, Sweden and the United States the payment wedges are rather "clustered" reflecting little incentive to shift between employment forms for tax reasons (individual or firm-re-

33 Milanez, Anna/Bratta, Barbara, Annex - Taxation and the Future of Work: How Tax Systems Influence Choice of Employment Form, in: OECD Taxation Working Paper Series, 42 (2019), p. 19, https://doi.org/10.1787/6b20cce5-en.

34 Ibid., p. 66. Similarly, for the Netherlands, p. 79: "[E]mployer's labour costs are deductible from the CIT base, irrespective of the type of worker."

35 Milanez, Anna, Gig Workers and the Tax Web (fn. 31).

36 Milanez, Annal Bratta, Barbara, Taxation and the Future of Work: How Tax Systems influence Choice of Employment Form (fn. 5).

37 Ibid., p. 60: "In summary, in the Netherlands, this analysis shows that the tax system provides an incentive for a firm to hire an unincorporated self-employed worker, as by doing so it pays a total employment cost of EUR 40,911 instead of EUR 64,960 for a standard employee or EUR 53,074 for an incorporated self-employed worker".

38 Ibid. The paper defines the average compulsory payment wedge ("payment wedge") as the net amount that government receives as a result of taxing income from work, inclusive of social contributions (SSCs and NTCPs), over the total employment cost of the worker under consideration.

39 Ibid., pp. $55 \mathrm{f}$. 
lated), whereas in countries like the Netherlands and Argentina payment wedges vary greatly, reflecting the opposite outcome. ${ }^{40}$ In this latter scenario, "[ $t]$ his translates into a tax system incentive for firms to contract labour rather than offer standard employment contracts, potentially misclassifying workers in the process. It also implies a tax system that incentivises individuals to become self-employed." 41

\section{Tax Issues and Employment Relationship: National Responses}

The classification of platform workers is crucial not only for social security contribution purposes, but also for tax purposes. When someone qualifies as an employee, it is the employer that has to withhold (at least part) of the taxes from the employee's salary. In contrast, when someone qualifies as self-employed or as an independent contractor, he/she is responsible for declaring his/her income and for paying taxes (and social security contributions) accordingly, saving the company significant administrative costs. There are certainly variations with regard to the applicable tax rates, the minimum taxable income, the deduction of business expenses etc. Usually, in addition to paying income tax, a self-employed person who provides some sort of services is liable to pay VAT.

Thus, the definition of the work status of the service providers/suppliers becomes essential, equally for labour law, social law and tax law. Obviously, such a universal or pan-European allocation of work status in the sharing economy or per platform does not exist, not least because such rules do not even exist even for the traditional forms of work. A lawyer, a plumber and an artist are taxed differently in different countries, depending on how much they work, where they work, whether this is their main or ancillary activity and considering many more factors. Equally, this difference in taxation may be expressed via different applicable tax rates, different tax bases (the income to be taxed) and as such, different allowances and deductions. Things get even more complex when we consider a cross-border scenario, even in the traditional (non-digital) understanding of work.

The context of the collaborative economy makes it even more difficult to answer the crucial questions of who should pay/withhold taxes, where taxes should be paid and what kind of taxes should be paid. There are several reasons for that. 1) The uncertainty as to the qualification of the type

40 Ibid.

41 Ibid., p. 66. 
of work performed. For instance, the Uber driver may have a different status in different countries ranging from an employee to an independent contractor. This classification affects not only the direct taxes he will have to pay but also the requirement of VAT registration and payment. Similarly, his status may change if he works for "BlaBlaCar". 2) The nature of services provided in the sharing economy and the lack of reporting standards make it easier for the shadow economy and undeclared work to flourish. ${ }^{42} 3$ ) The majority of platform workers work in at least one more job, resulting in the fragmentation of their income. ${ }^{43}$ For instance, someone may be resident in France, rent out an apartment he has in Portugal via Airbnb and, at the same time, provide online consultancy advice to a company in Belgium. In such a multi-state scenario, it is possible that the person at issue does not even know where to report the income he made from the use of different platforms.

A question that arises frequently is who has the final say in this classification. There is no obvious or clear answer to this question that would allow for a coherent legal framework. Reis and Chand provide for a good account of recent judgments in different countries that found Uber drivers to be either employees or independent contractors, considering a number of (similar) criteria. ${ }^{44}$

42 See for instance, OECD, Shining Light on the Shadow Economy: Opportunities and Threats, 2017, p. 19, https://www.oecd.org/tax/crime/shining-light-on-the-sha dow-economy-opportunities-and-threats.pdf. Accessed 10 July 2020. Where one of the main issues tax-related to the sharing economy was identified as: "since there is usually no traditional employer, payments received will not generally be visible to the tax administrations in the way, for example, that they are for salaried employees in many countries." I will come back to this point in Section IV. 3.

43 See for instance, OECD, Automation and Independent Work in a Digital Economy, Policy Brief, May 2016, OECD Publishing, Paris, p. 4, https://www.oecd.org/e ls/emp/Policy\%20brief\%20-\%20Automation\%20and\%20Independent $\% 20$ Work\% 20in\%20a\%20Digital\%20Economy.pdf. Accessed 10 July 2020: "As workers in the "platform economy" are more likely to have multiple jobs and income sources, the role and meaning of traditional labour market institutions are being challenged."

44 Reis, Ariene/Chand, Vikram, Uber Drivers: Employees or Independent Contractors?, in: Kluwer International Tax Blog, 3 April 2020, http://kluwertaxblog.com/2 020/04/03/uber-drivers-employees-or-independent-contractors/?doing_wp_cron=1 591797547.0120589733123779296875. Accessed 10 June 2020. 
For example, the UK employment tribunal dealt with a case about the employment status of Uber drivers. ${ }^{45}$ That tribunal was asked whether Uber drivers qualified as self-employed/independent contractors or as employees/workers. In defining whether Uber drivers should be treated as contractors, the tribunal looked into whether income tax and UK national insurance were deducted from their pay. Conversely, to determine their tax liability, the "tax test" would have had to look at their holiday pay, sick pay and pension rights. ${ }^{46}$ The UK employment tribunal concluded that Uber's drivers were to be classed as workers with access to minimum wage, sick pay and paid holidays, although they treated themselves as self-employed persons for tax purposes. ${ }^{47}$ The decision was also upheld by the Employment Appeal Tribunal ${ }^{48}$ and the Court of Appeal. ${ }^{49}$

The case highlights the distinction between labour law, social security contributions and tax law in the sharing economy and raises the question of whether there is a need to coordinate these interrelated policy areas. The 2018 OECD Interim Report identified this distinction as one of the thorniest issues in the sharing economy context. ${ }^{50}$ As different states provide for different tax incentives or disincentives, depending on the type of labour contract at issue, sharing economy features (and uncertainties) within the tax system could lead to tax revenue losses if there are large shifts in working patterns and taxable status. ${ }^{51}$ Another pertinent question is who decides on the qualification of the status of the "worker". For instance, the judgment of the UK employment tribunal seemed to cross-cut between the tax treatment of Uber drivers, which is, in turn, informed by the drivers' access to certain social security benefits. In some countries, it appears that "priority" is given to the designation made by the tax authorities and whether the Uber driver, for instance, falls within the given tax defini-

45 UK Employment Tribunal Judgement of 28 October 2016, Case No. 2202550/2015, Aslam and Farrar and Others v. Uber BV, Uber London Ltd and Uber Britannia Ltd (hereinafter "UK Uber Case").

46 Sayliss, Leigh, Be Careful What You Wish for, in: Taxation, 178 (2016) 4579.

47 UK Uber Case (fn. 45), para. 65.

48 UK Employment Appeal Tribunal Judgement of 10 November 2017, Appeal No. UKEAT/0056/17/DA, Aslam and Farrar and Others v. Uber BV, Uber London Ltd and Uber Britannia Ltd.

49 UK The Court of Appeal Judgement of 19 December 2018, Case No. A2/2017/3467, Aslam and Farrar and Others v. Uber BV, Uber London Ltd and Uber Britannia Ltd.

50 OECD, 2018 OECD Interim Report (fn. 8), p. 196.

51 Ibid., p. 196. 
tion. ${ }^{52}$ The problem is circular in that, if the definition is informed by, for instance, the access to social security benefits, as happened in the Uber UK case, then the different criteria and classifications may lead to contradictory results. What if, for example, one is classified for tax purposes as an employee but his employer does not pay for social security contributions? Which classification will take precedence and how will the classification for labour law purposes be made?

In Switzerland, there seems to be general consensus that Uber drivers should be classified as employees. ${ }^{53}$ The French Cour de Cassation also agreed that Uber drivers should be characterised as employees on the premise that they do not have independence in fixing their price or building their clientele. ${ }^{54}$

In the US, the classification of "gig workers" has created a lot of tension between platforms and workers, upon the delivery of the famous judgment of the California Supreme Court. ${ }^{55}$ The judgment dealt with the applicable standards in determining whether workers should be classified as employees or as independent contractors for purposes of California Wage Orders. ${ }^{56}$ Pursuant to the judgment that suggested a new presumption that all workers be employees instead of contractors, unless the employer proves otherwise under the newly adopted "ABC test", 57 the State of California approved, with effect from 1 January 2020, the California Assembly Bill 5 ("AB-5") incorporating the "ABC test". ${ }^{58}$ Under this test, for a worker to be classified as a contractor, the employer will have to prove that: (A)

52 Such an example is Denmark.

53 With regard to that see Reis, Ariene/Chand, Vikram, Uber Drivers: Employees or Independent Contractors? (fn. 44); the references made there to SUVA, SECO and UNIA and judgments by domestic courts.

54 Arrêt No. 374 du 4 mars 2020 (19-13.316), Cour de Cassation - Chambre Sociale, FR:CCAS:2020:SO00374, https://www.courdecassation.fr/jurisprudence_2/chamb re_sociale_576/374_4_44522.html, or in English: https://www.courdecassation.fr/I MG/20200304_arret_uber_english.pdf. Both accessed 15 May 2020.

55 Win, Suzin, The Bill That Disrupted the Gig Economy: AB-5 and Uber's Troubling Response, in: GGU Law Review Blog, 2 March 2020, https://ggulawreview.c om/2020/03/02/the-bill-that-disrupted-the-gig-economy-ab-5-and-ubers-troubling-r esponse/. Accessed 10 June 2020.

56 Supreme Court of California Judgement of 30 April 2018, Dynamex Operations West, Inc. v. Superior Court of Los Angeles, https:/law.justia.com/cases/california /supreme-court/2018/s222732.html. Accessed 10 June 2020.

57 Ibid.

58 For the text of the Bill, see California State Legislature, Worker Status: Employees and Independent Contractors, 19 September 2019, https://leginfo.legislature.ca.go v/faces/billNavClient.xhtml?bill_id=201920200AB5. Accessed 13 July 2020. 
the worker is free from the control and direction of the hiring entity in connection with the performance of the work, both under the contract for the performance of the work and in fact; (B) the worker performs work that is outside the usual course of the hiring entity's business; and $(\mathrm{C})$ the worker is customarily engaged in an independently established trade, occupation, or business of the same nature as the work performed. The three criteria are cumulative, therefore, if one of the three conditions is not met then an employment relationship between the employee and the worker will be established.

As it appears very likely that an Uber driver (though not an Airbnb host) will not meet the $\mathrm{ABC}$ test, and, hence, will be qualified as an employee, the Bill has sparked reactions from Uber and like companies. In the fear that approximately $\$ 500$ million a year will be added to Uber's labour costs and payroll taxes Uber filed a lawsuit in federal court challenging the constitutionality of AB-5 and sent an email to more than 150,000 California drivers and millions of passengers, notifying a change in the way they conduct the service. ${ }^{59}$ These changes consist in giving more freedom to the drivers to select their passengers and destinations to escape condition (A).

Despite these positive changes for gig workers at domestic or regional level, several other institutions and organisations have classified Uber drivers as independent contractors. ${ }^{60}$ Among the factors considered towards such a finding, the control of the drivers over their workload (how much, how often, when they can perform their work) was fundamental.

59 Win, Suzin, The Bill That Disrupted the Gig Economy: AB-5 and Uber's Troubling Response (fn. 55).

60 According to Reis, Ariene/Chand, Vikram, Uber Drivers: Employees or Independent Contractors? (fn. 44) such examples include the District Court of Pennsylvania in the US, United States District Court for the Eastern District of Pennsylvania, Ali Razak, Kenan Sabani and Khaldoun Cherdoud v. Uber Technologies Inc., Civil Action No. 16-573, 11 April 2018; the State of Florida in the US, Third District Court of Appeal of State of Florida, Darrin E. McGillis v. Uber, No. 3D15-2758, Lower Tribunal No. 0026283468-02, 1 February 2017 and the Brazilian Superior Labour Court that pronounced Uber drivers are contractors. In Australia in June 2019, the Fair Work Ombudsman decided to qualify Uber drivers as independent contractors, https:/www.fairwork.gov.au/about-us/news-and-mediareleases/2019-media-releases/june-2019/20190607-uber-media-release. Accessed 10 June 2020. 


\section{What can we Learn from Taxation?}

A common definition, or at least a common understanding of what constitutes an employment relationship, would facilitate the taxation of "platform workers". As highlighted, however, such a definition is lacking across countries, or at a supranational level, and even across inter-related sub-disciplines (labour law, tax law, social security contributions). Given the importance of the classification of gig workers either as employees or independent contractors, the lack of common criteria and the complex legal relationships in the platform economy have led to the paradoxical situation that one and the same person, the Uber driver for instance, may for labour law purposes be classified as an independent contractor, whereas for tax law and/or social security law purposes as an employee. The situation is even more complex when driving the Uber car is only an ancillary activity, and the Uber driver's main income is generated through different activities. Similarly, when the Airbnb host is resident in France and he rents out his villa in Portugal for 2 months per year. This section will examine the contribution of taxation in deciphering this complicated relationship in the context of the platform economy.

In a cross-border scenario, a worker's income may be taxed in multiple countries, the country/ies where he works (source state(s)) and the country where he resides (residence state). In order to limit or eliminate double taxation, countries usually conclude Double Tax Treaties (DTTs). In a noncross-border scenario where an employee resides and works in the same place, obviously there would not be much doubt as to where his income from employment should be taxed, although in the context of the platform economy his work may not be visible to the tax authorities. Things get more complex, however, in the case of frontier workers, or posted workers, or people with multiple jobs across the globe. In these cases, usually the DTTs aim, via their distributive rules, to "allocate taxing rights" between the involved states. This allocation does not imply that the DTT creates a taxing right in one state, but it rather suggests that if the income from employment has already been taxed in state A (source state), then state B (the residence state) should refrain from taxing the income again and provide for relief from the double taxation that would otherwise arise. ${ }^{61}$ In absence of a DTT, then in principle both the source state and the residence state would have a right to tax.

61 The relief is usually provided either via the exemption method (Article 23A OECD MC) or the credit method (Article 23B OECD MC). 
These DTTs usually follow the Organisation for Economic Cooperation and Development Model Convention on Income and Capital (hereinafter OECD MC). ${ }^{62}$ Article 15 of the OECD MC provides that when employment is exercised in a country other than the residence country, then salaries, wages and other similar remuneration shall be taxed in the source state, in other words the state where employment is performed. The double taxation that could arise may, thus, be resolved either via the applicable DTTs or in an intra-EU scenario, by resorting to the non-discrimination principle and the fundamental freedoms, provided some other conditions are met. ${ }^{63}$

\section{Double Tax Treaties and the OECD MC}

In social law, it has already been discussed whether the place of work rule (as a conflict of law rule of Regulation 883/2004) is still apt for social insurance purposes. Other options (based on the location of a platform provider or of a client) would, on the one hand, address the problem that platform providers and clients might try to take advantage of "a planetary labour market" in digital work, ${ }^{64}$ where platforms and clients can choose the cheapest platform workers (service providers) and countries without social and tax obligations imposed on platforms or clients. On the other hand, such options are inconsistent with the collection of social contributions at the source.

The underlying problem in both social law and tax law is finding a nexus to tax or to collect social security contributions in a digitalised world. It has been widely accepted that the rules defining the legal bases upon which a State may assert its tax jurisdiction over a particular taxpayer or an item of income (nexus rules) will have to be rewritten. ${ }^{65}$ The purpose of this section is to provide for an overview of the existing allocation rules

62 Developing countries usually follow the UN Model, which is similar (but not identical) to the OECD MC.

63 There is extensive CJEU case law that requires, inter alia, that resident and nonresident taxpayers are found to be in a comparable situation.

64 Graham, Mark/Anwar, Mohammad Amir, The Global Gig Economy: Towards a Planetary Labour Market? in: First Monday, 24 (2019) 4.

65 Gadzo, Stjepan, New Nexus for the Digital Economy: An Analysis of Digital, Revenue-Based and User-Based Factors, in: Pistone, Pasquale/Weber, Dennis (eds.), Taxing the Digital Economy: The EU Proposals and other Insights, Amsterdam: IBFD 2019, p. 93. 
with regard to income from employment, in order to investigate whether they can provide a) for any useful guidance as to the distinction between independent contractors and employees and b) whether they are still apt for use in the context of the platform economy.

According to the OECD MC, different taxing allocation rules exist depending on the activity of the "worker". Thus, different provisions exist for entertainers and sportspersons whose income may be taxed in the state where they perform (Article 17 OECD MC), pensions that are usually taxable in the state of residence of the recipient (Article 18 OECD MC), government services (Article 19 OECD MC) and students (Article 20 OECD $\mathrm{MC}$ ). Of relevance for the purposes of taxation of workers and/or self-employed persons are also Article 7 OECD MC on business profits, as well as the definition of what constitutes a Permanent Establishment (hereinafter PE) in Article 5 OECD MC, and when and how profits can be attributed to it. If an enterprise carries out business through a PE, the profits that are attributable to the PE may be taxed in the state of the PE. Such may be the case, for instance, when a company carries out business in another state via a dependent agent. ${ }^{66}$

While the aforementioned provisions will at first appear rather evident as to their application in a cross-border scenario, there are too many variables to be considered in order to answer where the particular income will be taxed, and how it will be taxed. These variables include factual assessments, such as the frequency with which a frontier worker returns to his "home country" during a fiscal year; ${ }^{67}$ as well as interpretative assessments including qualification of the particular income, ${ }^{68}$ residence qualification and qualification (or absence thereof) of the "employee" status. This ensuing lack of coordination becomes all the more visible in the context of the digital economy, whereby physical presence is not essential and the type of work provided is uncertain in terms of frequency, ancillary character and legal definition.

66 For more information on the distinction between dependent and independent agent, see paragraph 32 of the OECD MC Commentary on Article 5.

67 See, for instance, Article 15 (2) of the OECD MC.

68 For instance, does the income at issue qualify as income from employment or as business profit? The distinction is not always clear and depends also on the qualification of the person at issue as employed or self-employed. 
However, the OECD MC could be of assistance in understanding the concept of employment in international tax law. Article 15 (1) and (2) OECD MC read: 69

"1. Subject to the provisions of Articles 16, 18 and 19, salaries, wages and other similar remuneration derived by a resident of a Contracting State in respect of an employment shall be taxable only in that State unless the employment is exercised in the other Contracting State. If the employment is so exercised, such remuneration as is derived therefrom may be taxed in that other State.

2. Notwithstanding the provisions of paragraph 1, remuneration derived by a resident of a Contracting State in respect of an employment exercised in the other Contracting State shall be taxable only in the first-mentioned State if:

a) the recipient is present in the other State for a period or periods not exceeding in the aggregate 183 days in any twelve month period commencing or ending in the fiscal year concerned, and

b) the remuneration is paid by, or on behalf of, an employer who is not a resident of the other State, and

c) the remuneration is not borne by a permanent establishment which the employer has in the other State."

Article 15 OECD MC includes several undefined terms, on which the Commentary attempts to shed some light. ${ }^{70}$ However, the concept of employment itself is not analysed in the Commentary. Instead, the Commentary only acknowledges that "[...] the issue of whether or not services are provided in the exercise of an employment may sometimes give rise to difficulties which are discussed in paragraphs $8.1 \mathrm{ff}{ }^{71}$ Yet, one could argue

69 Note the change in the title of Article 15 OECD MC in 2000, from "Dependent Personal Services" to "Employment". The amendment followed the elimination of Article 14 OECD MC which referred to "Independent Personal Services".

70 For a discussion on the many undefined terms, see Peeters, Bernard, Article 15 of the OECD Model Convention on "Income from Employment" and its Undefined Terms, in: European Taxation, 44 (2004) 2, pp. 72-82.

71 Commentary on Article 15 (1) OECD MC (2017 version). See also para. 8.1. of the Commentary on Article 15 (1) OECD MC that provides: "It may be difficult, in certain cases, to determine whether the services rendered in a State by an individual resident of another State, and provided to an enterprise of the first State (or that has a permanent establishment in that State), constitute employment services, to which Article 15 applies, or services rendered by a separate enterprise, to which Article 7 applies or, more generally, whether the exception applies." 
that from the remaining Commentary some valuable characteristics of what constitutes employment in this particular context could be derived.

Subject to the limit described in paragraph 8.11 and unless the context of a particular convention requires otherwise, it is a matter of domestic law of the State of source (i.e. the place where the employment is exercised) to determine whether services rendered by an individual in that State are provided in an employment relationship and that determination will govern how that State applies the Convention. ${ }^{72}$ In such cases, the relevant domestic law may ignore the way in which the services are characterised in the formal contracts. It may prefer to focus primarily on the nature of the services rendered by the individual and their integration into the business carried out by the enterprise that acquires the services to conclude that there is an employment relationship between the individual and that enterprise. ${ }^{73}$ The Commentary then goes on to give guidance on when a formal contractual employment relationship should be disregarded, taking into account the relevant facts and circumstances. ${ }^{74}$ As already mentioned, the distinction between "employment services" and "services rendered under a contract for the provision of services" 75 is important for the application of the relevant DTT article and the allocation of taxing rights between the states. ${ }^{76}$ The Commentary encourages the involved states to solve any disagreement as to the qualification of the work relationship having regard to the nature of the services rendered by the individual. In this bid, according to the Commentary, when the services rendered by the individual constitute an integral part of the business of the enterprise to which these services are provided, "it is logical to assume" that an employee will be providing such services. ${ }^{77}$ For that purpose, a key consideration will be which enterprise bears the responsibility or risk for the results produced by the individual's work.

72 Para. 8.4. of the Commentary on Article 15 (1) OECD MC (2017 version).

73 Para. 8.7. of the Commentary on Article 15 (1) OECD MC (2017 version).

74 See notably para. 8.11. of the Commentary on Article 15 (1) OECD MC (2017 version): "For instance, a State could not argue that services are deemed, under its domestic law, to constitute employment services where, under the relevant facts and circumstances, it clearly appears that these services are rendered under a contract for the provision of services concluded between two separate enterprises."

75 Similar to the concept of the independent contractor.

76 In the case of the independent contractor, Article 7 OECD MC would apply whereas in the case of employment, Article 15 OECD MC would apply. The two articles allocate in a different manner the taxing rights of the residence and the source state.

77 Para. 8.13. of the Commentary on Article 15 (1) OECD MC (2017 version). 
Additional factors and questions to be taken into account when determining the working relationship, include: ${ }^{78}$

- who has the authority to instruct the individual regarding the manner in which the work has to be performed;

- who controls and has responsibility for the place at which the work is performed;

- whether the remuneration of the individual is directly charged by the formal employer to the enterprise to which the services are provided;

- who puts the tools and materials necessary for the work at the individual's disposal;

- who determines the number and qualifications of the individuals performing the work;

- who has the right to select the individual who will perform the work and to terminate the contractual arrangements entered into with that individual for that purpose;

- who has the right to impose disciplinary sanctions related to the work of that individual;

- who determines the holidays and work schedule of that individual.

These indicative factors do not provide for any clear solutions as to the qualification of gig workers. As Reis and Chand observe, both indications of employment (some degree of subordination and control by the company) and of independent services (flexibility of the drivers) can be met in the case of Uber drivers. ${ }^{79}$ Consequently, while the OECD MC provides for some indicia that could lead to the platform workers' classification, the "hybridity" of many platform models that encompass worker characteristics of both an employee and a contactor cannot be resolved by solely relying on the Commentary. In case of no agreement between the states, the Commentary advises to use, where appropriate, the mutual agreement procedure (MAP) to resolve the tax dispute.

78 The factors as appear in para. 8.14. of the Commentary on Article 15 (1) OECD MC (2017 version). Note that the Commentary suggests that these are "additional factors [that] may be relevant to determine whether this is really the case [i.e. a formal employment relationship or a contract on the provision of services].”

79 Reis, Ariene/Chand, Vikram, Uber Drivers: Employees or Independent Contractors? (fn. 44). 


\section{Can VAT Provisions be of any Help?}

\section{a) Carrying out Activities "Independently"}

The payment of indirect taxes, specifically VAT, may also provide for guidance with respect to the distinction between independent contractor and employee in the context of the platform economy. In general, employees are not required to register for and pay VAT, unlike independent contractors. One of the distinguishing criteria is, once again, the exercise of activities "independently". Article 10 of the EU VAT Directive provides that the requirement of "independent" activity, to qualify as a VAT "taxable person" ${ }^{80}$ excludes "employed and other persons from VAT in so far as they are bound to an employer by a contract of employment or by any other legal ties creating the relationship of employer and employee as regards working conditions, remuneration and the employer's liability." Therefore, the concept of independence becomes once again essential in informing the distinction between independent contractor and employee. ${ }^{81}$

In the Court's case law, the three criteria used to determine whether an activity is carried out independently, include: a) whether it is exercised by a person who is not organically integrated into the undertaking; b) whether the person at issue has the appropriate organisational freedom with regard to the human and material resources used in the exercise of the relevant activity; and c) whether the person at issue bears any economic risk when performing the relevant activity.

It is obvious that an evaluation of the aforementioned criteria necessitates an ad hoc factual assessment. The CJEU has provided guidance as to the concept of independence in the context of the VAT Directive in several cases. ${ }^{82}$ Applying these criteria in the platform economy, one may note that usually "gig workers" are not organically integrated into the platform,

80 For the concept of the "taxable person" in EU VAT law see Article 9 (1) Council Directive 2006/112/EC of 28 November 2006 on the Common System of Value Added Tax (hereinafter EU VAT Directive), https://eur-lex.europa.eu/eli/dir/2006/ 112/oj. Accessed 14 July 2020; analysed right below.

81 Note, however, that the concept of "employee" is not defined anywhere in the VAT Directive.

82 See for instance, CJEU of 18 October 2007, Case C-355/06, van der Steen, ECLI:EU:C:2007:615, where the CJEU ruled that since the sole director at issue received regularly his salary regardless of the company's financial situation, he could not qualify as independent supplier and, hence, was not a taxable person for VAT purposes. Also, CJEU of 12 October 2016, Case C-340/15, Nigl, ECLI:EU:C:2016:764. 
they have sufficient organisational autonomy to decide whether to drive their cars or rent their properties, and that their remuneration is not regular and secured in that it depends on the number of transactions concluded. The "independent activity" criteria, therefore, as enshrined in Article 10 of the EU VAT Directive are usually met. However, this does not suffice to qualify a "gig worker" as a "taxable person" for VAT purposes. Article 9 provides for a number of further conditions, which I turn to examine now.

\section{b) Taxable Person}

According to the EU VAT Directive, the definition of a taxable person includes any person or entity "who, independently, carries out in any place any economic activity, whatever the purpose or results of that activity". ${ }^{83}$ Hence, employed and other persons bound to an employer by a contract of employment or by any other legal ties creating the relationship of employer and employee as regards working conditions, remuneration and the employer's liability, escape taxability under the VAT Directive.

The test the CJEU usually applied to establish whether a particular activity, including the renting out of property, fulfils Article 9 (1) of the VAT Directive examines whether the activity is carried out for the purpose of obtaining income on a continuing basis. ${ }^{84}$ This criterion must be assessed on a case-by-case basis "having regard to all the circumstances of the case, which include, inter alia, the nature of the property concerned". ${ }^{85}$

The term "economic activity" has been interpreted by the CJEU in very broad terms, considering the activity per se rather than its purpose or results. ${ }^{86}$ Along these lines, the CJEU has repeatedly held that: "[T]he fact

83 Article 9 (1) EU VAT Directive. With regard to the second condition (i.e., independent performance), it may be concluded that in cases where the sharing platform can be recognised as an employer of an individual provider (for the latter, the criteria of the existence of a subordination link, the nature of work and the presence of remuneration should be assessed pursuant to EU law), the individual provider may not be regarded as a taxable person. In such cases, only the sharing platform may be regarded as a taxable person instead - also with regard to underlying supplies of goods and services.

84 CJEU of 19 July 2012, Case C-263/11, Rēdlihs, ECLI:EU:C:2012:497, para. 33; CJEU of 20 June 2013, Case C-219/12, Finanzamt Freistadt Rohrbach Urfahr, ECLI:EU:C:2013:413, para. 19.

85 Ibid., Rēdlihs, para. 29.

86 CJEU of 12 January 2006 Joined Cases C-354/03, C-355/03 and C-484/03, Optigen Ltd, Fulcrum Electronics Ltd, Bond House Systems Ltd v. Comm'n, 
that [the] property is suitable only for economic exploitation will normally be sufficient for a finding that its owner is exploiting it for the purposes of economic activities and, consequently, for the purpose of obtaining income on a continuing basis. By contrast, if, by reason of its nature, property is capable of being used for both economic and private purposes, all the circumstances in which it is used will have to be examined in order to determine whether it is actually being used for the purpose of obtaining income on a continuing basis (emphasis added)".$^{87}$

Consequently, if the property is, due to its nature, clearly used for purposes of obtaining income on a continuing basis, then it (the economic activity) will be subject to VAT. If the use of the property, as matter of fact, is not clear, then a more complex, factual analysis will be necessary to assess whether the activity is carried out for the purpose of obtaining income on a continuing basis.

Several issues arise with respect to whether "platform workers" are (and should be) subject to VAT. At first sight, the CJEU-made "continuity" condition seems to be rebuttable: for instance, in the case of Airbnb rentals, if one shows that the purpose of renting out the property for a very short period did not aim at "obtaining income on a continuing basis", then the activity will not be subject to VAT. Hence, in a strictly literal interpretation of the phrase, it remains unclear whether someone who has rented out his apartment every August for the past five years should be assessed. Recent legislation in some countries has reduced, for non-tax-related reasons, the number of days a service provider can provide short-term rentals of his immovable property. ${ }^{88}$

Article 12 of the VAT Directive attempts to ensure that even these service providers can be made subject to VAT: it stipulates that "Member States may regard as a taxable person anyone who carries out, on an occasional basis, a transaction relating to the activities referred to in the second subparagraph of Article 9 (1)" (emphasis added). While the CJEU has held that the mere exercise of the right of ownership and the management of

ECLI:EU:C:2006:16, para. 43 and CJEU of 26 March 1987, Case C-235/85, Comm'n v. Netherlands, ECLI:EU:C:1987:161, para. 8.

87 CJEU of 19 July 2012, Case C-263/11, Rēdlihs, ECLI:EU:C:2012:497, para. 34; CJEU of 20 June 2013, Case C-219/12, Finanzamt Freistadt Rohrbach Urfahr, ECLI:EU:C:2013:413, para. 20.

88 In Paris, for instance, short-term rentals (Airbnb type) were reduced by law to a maximum of 120 days per year. In Amsterdam, owners will be able to rent out their property through Airbnb only for thirty days per year. 
the private property do not constitute economic activity, ${ }^{89}$ it has also ruled that if the party has taken active steps to market property by mobilising resources similar to those deployed by producers, traders or persons supplying services within the meaning of Article 4 (2) of the [VAT] Directive, such as, in particular, "the carrying out on that land of preparatory work to make development possible, and the deployment of proven marketing measures," then such initiatives go beyond mere exercise of the management of the private property. ${ }^{90}$ In other words, marketing or advertising the property constitutes, in the CJEU's view, the distinctive element that separates the mere management of private property from its economic exploitation.

This very broad, CJEU understanding has led the Commission to suggest that:

"Given the very wide understanding of the concept of economic activity $[\ldots]$ it can be therefore concluded that the supplies of goods and services made through sharing-economy platforms, such as driving customers to requested destinations or renting out immovable property may qualify as an economic activity in the sense of the VAT Directive irrespective of whether such supplies are delivered with clear continuity or on a more occasional basis" (emphasis added). ${ }^{91}$

Indeed, under these circumstances, and as the Commission notes, it seems almost impossible for "platform workers" to escape the "taxable person" definition. In the Airbnb and Uber scenarios, therefore, once someone uploads an apartment for rent or avails himself of the opportunity, through the Uber platform, to drive someone to that person's destination, he auto-

89 CJEU of 15 September 2011, Joined Cases C-180/10 \& C-181/10, Słaby \& Others, ECLI:EU:C:2011:589, para. 36; CJEU of 9 July 2015, Case C-331/14, Trgovina Prizma, ECLI:EU:C:2015:456, para. 23.

90 CJEU of 15 September 2011, Joined Cases C-180/10 \& C-181/10, Słaby \& Others, ECLI:EU:C:2011:589, para. 39-41; CJEU of 9 July 2015, Case C-331/14, Trgovina Prizma, ECLI:EU:C:2015:456, para. 24.

91 European Commission, Question Concerning the Application of EU VAT Provisions: VAT Treatment of Sharing Economy 6, Value Added Tax Comm., Working Paper No. 878, 22 September 2015, https://circabc.europa.eu/sd/a/878e0591-80c94c58-baf3-b9fda1094338/8

78\%20-\%20VAT\%20treatment\%20of\%20sharing\%20economy.pdf. Accessed 14 July 2020. 
matically becomes a taxable person for VAT purposes, even if he only does so on an occasional basis. ${ }^{92}$

Beretta lists the following as the main conditions to check whether an individual supplier carries out an economic activity pursuant to Article 9 of the VAT Directive: non-exclusionary membership, organisational autonomy, economic risk, regulatory autonomy, remuneration independence and personal liability. ${ }^{93} \mathrm{He}$ uses four different platforms to evaluate whether these criteria are met: Airbnb, Uber, HomeExchange and BlaBlaCar and he notes that the assessment varies significantly depending on the platform at issue. ${ }^{94}$ Upon carrying out a functional analysis, he concludes that only Uber drivers "might eventually be recharacterised as employees of the platform" as long as they tick more than half of the criteria listed..$^{95}$

\section{c) Economic Activity/ Income Definition}

Although one would expect that the definition of the type of work precedes the income definition, it is noteworthy to examine the questions that pertain to what kind of income should be taxed. To exemplify the problem, income arising from renting property via Airbnb could be classified as either income from immovable property or income from business.

The distinguishing criterion in answering this question is a thorny issue. The remuneration or "income" the platform worker receives varies widely depending on the platform itself and the worker himself. As the Commission pointed out, such income could range from "recovering costs (e.g.[,] for the personal use of a good such as in ride-sharing/car sharing) to amounts comparable to business/work activities." 96 While the Commission suggests that "tax rules should follow national laws and jurisprudence,

92 The only obvious escape from the application of VAT in such circumstances would be the application of the de minimis exemption from VAT reporting. In this vein, some Member States have established a minimum annual turnover for VAT imposition (VAT registration threshold). See subsection below.

93 Beretta, Giorgio, European VAT and the Sharing Economy, Alphen aan den Rijn: Wolters Kluwer 2019, p. 99.

94 Ibid.

95 Ibid.

96 European Commission, Communication from the Commission to the European Parliament, the Council, the European Social and Economic Committee and the Committee of the Regions on A European Agenda for Collaborative Economy, COM (2016) 356, p. 41 (hereinafter EU Collaborative Economy Agenda), avail- 
which determine from which moment an activity becomes a business activity," 97 income is not defined in a uniform manner across the Member States. That fact adds to the uncertainty of the definition of what constitutes an economic activity, according to the test the CJEU employs. Accordingly, the same activity may constitute an economic activity for VAT purposes in one Member State and not in another because the remuneration at issue does not qualify as income. If one adds to that situation the different thresholds Member States apply by reference to what constitutes a "professional activity" vis-à-vis an "occasional" activity of private individuals, the fulfilment of the aforementioned definitions becomes even more segregated.

Another interpretation difficulty across the different Member States relates to the exemption of "small businesses" (i.e., businesses with low annual turnover) from VAT registration. ${ }^{98}$ This special exemption scheme is applied in most EU Member States, but it is not compulsory. Unfortunately, the VAT Directive does not specify whether "small taxable persons" who participate in the sharing economy (e.g., somebody who occasionally rents out his apartment) can benefit from such exemption schemes. One (administratively burdensome!) option would be to treat them all as "fullblown taxable persons" based on "tax points". 99 The other option would be to extend the special rules for small businesses to the "small taxpayers" in the context of the sharing economy. ${ }^{100}$

As a yardstick for measuring the level of business activity, a person's annual turnover, exclusive of VAT, is generally used. ${ }^{101}$ However, registration thresholds vary consistently among Member States. Some Member States set very high thresholds before a person incurs VAT payment obligations. Italy for instance, sets a registration threshold at EUR 65,000, whereas Fin-

able at https:/ec.europa.eu/transparency/regdoc/rep/1/2016/EN/1-2016-356-EN-F 1-1.PDF. Accessed 10 June 2020.

97 Ibid.

98 Articles 284-287, EU VAT Directive. Member States are allowed to exempt small businesses from VAT registration up to a given threshold.

99 Kogels, Han/van Hilten, Markien, Never a Dull Moment, in: International VAT Monitor, 28 (2017) 2, p. 121. Tax points (or "time of supply") for a transaction is the date the transaction takes place for VAT purposes. Tax points can be, for instance, the date of invoice or the day the supply took place.

100 Ibid., p. 122.

101 Beretta, Giorgio, VAT and the Sharing Economy, in: World Tax Journal, 10 (2018) 3, pp. 381, 414. 
land and Greece do so at only EUR 10,000. ${ }^{102}$ It is doubtful how many Airbnb hosts would reach the Italian threshold, and how much the market would be distorted due to these differences. ${ }^{103}$ Some other Member States, such as Greece, grant service providers an exemption from VAT as long as the host does not provide any services similar to the ones offered by hotels, such as regular cleaning and linen changes. ${ }^{104}$

A remedy against potential tax evasion that could arise from the nonpayment of VAT by platform workers is the collection of such VAT by the relevant platform (in addition to any other taxes they collect), provided, however, that the hosts have exceeded the threshold for VAT registration. This would presuppose an updated and informed reporting system between the platform and the platform worker. This way, all relevant details that would define the amount to be paid by the taxpayer would already be available to the platform and the risk of tax evasion would be minimised.

\section{Enforcement and Collection}

An additional problem that is created by blurring the boundaries between employment and self-employment in the platform economy is the difficulty for the authorities to "follow the money". ${ }^{105}$ The lack of visibility of the activity and the inability to identify potential taxpayers and their taxable income has cost the tax authorities billions of tax revenue. ${ }^{106}$ This obviously poses obstacles to effective taxation and collection of taxes. The solutions

102 For VAT registration thresholds, see https://www.avalara.com/vatlive/en/eu-vat-r ules/eu-vat-number-registration/vat-registration-threshold.html. Accessed 14 July 2020.

103 Houlder, Vanessa, Airbnb's Edge on Room Prices Depends on Tax Advantages, Financial Times, 2 January 2017, https:/www.ft.com/content/73102c20-c60e-11e 6-9043-7e34c07b46ef, reported that: "When you book an Airbnb room in London, around a third of the USD 100 saving you make over the price of an average hotel room is due to tax advantages that favour Airbnb's business model.” Accessed 13 July 2020.

104 Article 111 (4) of Law 4446/2016 as amended by Law 4472/2017.

105 Mineva, Daniela/Stefanov, Ruslan, Evasion of Taxes and Social Security Contributions. September 2018, European Platform Undeclared Work.

106 While estimates of lost tax revenue per country do not exist, this is a recurring theme. See for instance, OECD, Shining Light on the Shadow Economy: Opportunities and Threats (see fn. 42); Migai, Clement Okello/de Jong, Julia/Owens, Jeffrey, The Sharing Economy: Turning Challenges into Compliance Opportunities for Tax Administrations, in: eJournal of Tax Research, 16 (2018) 1, https://www. business.unsw.edu.au/About-Site/Schools-Site/Taxation-Business-Law-Site/Docu 
for effectively taxing the sharing economy, in the OECD's view, should focus on improving the effective taxation of activities facilitated by online platforms through improving taxpayer education and facilitating self-reporting. ${ }^{107}$ Effective taxation becomes, hence, a matter of collaboration between the platform and the taxpayer. This recommendation has been implemented by some Member States that have attempted to incentivise the service providers to include their income from the sharing economy when completing their tax returns through simplified procedures or automated, pre-prepared tax declarations available to the service providers directly through the platforms. In France, for example, as of July 2016, collaborative platforms have been legally obliged to communicate to each individual providing services in the sharing economy an annual summary of their tax situation, mentioning how to do their tax declaration and how much they have to declare to the tax authorities. ${ }^{108}$

Other countries, like Belgium, provide tax incentives to platform workers if the latter enrol with a platform and register their activities. ${ }^{109} \mathrm{Re}-$ duced taxation applies to platform workers who provide services up to a EUR 6,000 exemption threshold per year. ${ }^{110}$ The platform must share the income of the platform worker with the tax administration. If the income exceeds the EUR 6,000 cap, then the platform worker must register as selfemployed and be affiliated with the mandatory social security system for the self-employed.

A commonly used example of a successful strategy for simplifying and streamlining tax collection is Estonia. Upon working together with Uber, the Estonian Tax and Customs Board developed a (voluntary) income data reporting system that would simplify the tax declaration process for Uber drivers. The main idea was to minimise bureaucracy and facilitate automatic tax reporting for businesses and entrepreneurs. Consequently, transactions between the driver and the customer are registered by the collaborative platform, which then only sends the data that is relevant for taxation purposes to the authorities, who in turn will then pre-prepare the taxpay-

ments/The-sharing-economy-turning-challenges-into-compliance-CM-JdJ-JO.pdf. Accessed 14 July 2020.

107 OECD, 2018 OECD Interim Report (fn. 8), p. 198.

108 EU Collaborative Economy Agenda (fn. 96), p. 43.

109 In order for the platform worker to benefit from the tax exemption, the platform needs to be formally recognised by the Belgian authorities.

110 OECD, OECD Economic Surveys: Belgium, February 2020, p. 115, https://www. oecd.org/economy/surveys/Belgium-2020-OECD-economic-survey-overview.pdf. Accessed 14 July 2020. 
er's tax forms. The main idea is to help taxpayers fulfil their tax obligations effectively and with minimal effort. The voluntary income reporting system has been operational since the 2017 tax year and it is not limited to the ride sharing sector; all platform operators can use the system if they wish. However, it remains an "opt-in" system - if the platform decides not to join, then reporting relies on the "good will" of the platform worker. ${ }^{111}$

Denmark has also developed an automated income reporting system that could be used by all platforms. Currently, Denmark is testing the "technical pilot" in several platforms in order to investigate the technical feasibility of having an automated reporting scheme and a technology to support platforms and taxation. ${ }^{112}$ This reporting system necessitated a change in the Danish law in December 2018 stating that digital platforms that facilitate the letting of property (homes, cars, etc.) should report all income earned by users of the platforms to the Danish tax authorities. ${ }^{113}$

Mexico is another example of successful cooperation between the tax authorities, the platform and the service providers. By using data recording technologies that drivers of a particular ride-for-hire service are able to use, the platform's own systems file and send invoices to the customers and to the Mexican Tax Administration (Servicio de Administración Tributaria $(\mathrm{SAT})$ ), as well as download them for record-keeping purposes. ${ }^{114}$

In Australia, a consultation paper by the Treasury suggested that the reporting "burden" should be placed either at the platform level or at the financial institutions' level. ${ }^{115}$ Operators of sharing economy platforms should be required to collect and report to the Australian Taxation Office (ATO) key information such as identity details and income received by their sellers based in Australia. Some platforms may already provide transaction information on a regular basis to their sellers, which assists them to meet their tax or other obligations and can be used by the ATO to match

111 See also Ogembo, Daisy/Lehdonvirta, Vili, Taxing Earnings from the Platform Economy: An EU Digital Single Window for Income Data?, in: British Tax Review, 82 (2020) 1, pp. 92-93.

112 Ibid., p. 89.

113 Ibid. The authors also note that "[ $\mathrm{g}]$ ig work platforms were also considered but excluded from the scope of this initial legislation because of Denmark's complex social security legislation."

114 OECD, 2018 OECD Interim Report (fn. 8), p. 201. Drivers are obliged to register with the particular recording system of the platform.

115 The Australian Government Treasury, Tackling the Black Economy: A Sharing Economy Reporting Regime - A Consultation Paper in Response to the Black Economy Taskforce Final Report, January 2019, https://apo.org.au/node/216381. Accessed 10 June 2020. 
and potentially to pre-fill in tax returns. This will contribute to reducing the compliance burden on taxpayers. ${ }^{116}$ Alternatively, the financial institution or the payment processors, who would be required to report the transaction data to the tax authorities, could incur the reporting burden. Such an "opt-in" model - with variations - already exists in Estonia. ${ }^{117}$

In July 2020, the OECD released a new global tax reporting framework, the Model Rules for Reporting by Platform Operators with respect to Sellers in the Sharing and Gig Economy ("MRDP"). ${ }^{118}$ Under the MRDP, digital platforms are required to collect information on the income realised by those offering accommodation, transport and personal services through platforms and to report the information to tax authorities. While the model reporting rules included in the MRDP are not compulsory for "interested jurisdictions", they constitute a first consolidated effort by the OECD to codify on a uniform basis information collection and information reporting by specific platforms. This way, automatic exchange agreements between such interested jurisdictions will be facilitated, and the proliferation of different domestic reporting requirements will be contained.

\section{Conclusion}

Upon analysing the several problems and solutions provided from a tax perspective, the question remains: how can taxation be of use for social law? The first takeaway relates to the taxation of the platform. If platforms are tax-incentivised to "hire" contractors, then obviously, they will resist any change in the work relationship between them and the platform workers, as the Uber example in California demonstrates. By contrast, if platforms receive adequate tax deductions and credits that could set off the social security contributions they pay for employees, then a formal employment contract would be an option for both parties.

The second question relates to the issue as to who should identify the work relationship and under which criteria. While it is widely acknowl-

116 Ibid.

117 For details on the "small business account", see Chapter 11, Section V, pp. 299 et seq.

118 OECD, Model Rules for Reporting by Platform Operators with respect to Sellers in the Sharing and Gig Economy, OECD, Paris, 2020, https://www.oecd.org/tax/ exchange-of-tax-information/model-rules-for-reporting-by-platform-operators-wit h-respect-to-sellers-in-the-sharing-and-gig-economy.htm. Accessed 10 September 2020. 
edged that labour law, social law and tax law serve different purposes, and that the same person may be classified differently for social law or tax law purposes respectively, it appears that the criteria of dependence, subordination and freedom in the way to provide services are pertinent across jurisdictions and different legal areas, including within taxation (VAT and OECD MC). Even though, indeed, an ad hoc assessment will have to be performed each time, it is possible that the existing case law from these three interrelated areas may result in convergence towards one, uniformly applicable test. Such a coordinated approach would prevent resorting to circular arguments including the platform worker's tax treatment for labour law classification purposes, which may lead to contradictory results.

Finally, the discussion at policy level appears to be slowly including the taxation of platform workers and the revenue lost due to the platform shadow economy. Platform workers, even when they fall under the "independent contractor" status should be facilitated and encouraged to declare their income. A series of reporting measures has been proposed by several countries that often requires the cooperation of the platform, the worker and the tax authorities. Laudably, the OECD published very recently its Model Rules for Reporting by Platform Operators that aim to provide (in a consistent and uniform manner) guidance to jurisdictions as to the reporting rules to be adopted and applied to platforms. A combination of the right tax incentives at both platform and platform workers' level, together with a simplified reporting system would contribute to ensuring both adequate revenue to finance social security schemes as well as a framework that would assist in fighting bogus self-employment. 